\title{
PERBEDAAN TEKANAN DARAH DAN INDEKS MASSA TUBUH PADA AKSEPTOR SUNTIK KOMBINASI DAN SUNTIK DEPO MEDROXYPROGESTERON ASETAT (DMPA)
}

\author{
Rohmi Handayani, Siti Yulaikah \\ Kementerian Kesehatan Politeknik Kesehatan Surakarta Jurusan Kebidanan
}

\begin{abstract}
Blood Pressure, BMI, and Injectable DMPA Injectable Combination. Hormonal contraception is a type of contraception most widely used by women, especially in developed countries because of this effectiveness in preventing pregnancy. Hormonal contraceptives are currently available can be pills, injections or implants. Although effective in preventing pregnancy on the other hand can cause various side effects include is weight gain and increased blood pressure in the acceptor.The purpose of this reasearch is to determine differences in blood pressure rise acceptor combination hormonal injections and blood pressure acceptor DMPA injections and to determine differences in body mass index increase acceptors injectable hormonal combination with a body mass index in injectable DMPA acceptors.Type of this reasearch is an analytic survey with cross sectional study design. The population in this study are all injectable acceptor in the Klaten area totaling 95512 acceptors. The sample size is 500 samples taken which comprises a group acceptor and acceptor combined injectable DMPA injections. The sampling technique used in this research is purposive sampling. Analysis of data using non-parametric test with Mann Whitney test.There was no significant difference between the increase in systolic blood pressure acceptor and acceptor combined injectable DMPA injections, $P=0.338$. There was no significant difference between the increase in diastolic blood pressure acceptor and acceptor combined injectable DMPA injections, $P=0,917$.there was significant difference between the increase in BMI acceptor and acceptor combined injectable $D M P A$ injections, $P=0.000$.There was no significant difference between the increase in blood pressure and acceptor acceptor combined injectable DMPA injections. There is a significant difference between the increase in BMI acceptor and acceptor combined injectable DMPA injections.
\end{abstract}

Keywords: Blood Pressure, BMI, and Injectable DMPA Injectable Combination.

Abstrak: Tekanan Darah, IMT, Suntik Kombinasi dan suntik DMPA. Kontrasepsi hormonal merupakan jenis kontrasepsi yang paling banyak digunakan wanita terutama di negara-negara maju karena keefektifanya dalam mencegah kehamilan. Kontrasepsi hormonal yang beredar saat ini dapat berupa pil, suntik atau implan. Walaupun efektif dalam mencegah kehamilan disisi lain dapat menimbulkan berbagai efek samping di antaranya adalah peningkatan berat badan dan peningkatan tekanan darah pada akseptor.Tujuan penelitian ini adalah untuk mengetahui perbedaan kenaikan tekanan darah akseptor KB suntik hormonal kombinasi dan tekanan darah pada akseptor KB suntik DMPA dan untuk mengetahui perbedaan kenaikan indeks masa tubuh akseptor $\mathrm{KB}$ suntik hormonal kombinasi dengan indeks masa tubuh pada akseptor KB suntik 
DMPA. Jenis penelitian ini adalah survey analitik dengan desain penelitian cross sectional. Populasi dalam penelitian ini adalah seluruh akseptor suntik di wilayah Klaten yang berjumlah 95.512 akseptor. Besar sampel yang diambil adalah 500 sampel yang terdiri kelompok akseptor suntik kombinasi dan akseptor suntik DMPA. Teknik sampling yang digunakan dalam penelitian ini adalah purposive sampling. Analisis data menggunakan uji non parametrik dengan uji Mann Whitney.Tidak terdapat perbedaan yang bermakna antara kenaikan tekanan darah sistole akseptor suntik kombinasi dan akseptor suntik DMPA, nilai $P=0,338$. Tidak terdapat perbedaan yang bermakna antara kenaikan tekanan darah diastole akseptor suntik kombinasi dan akseptor suntik DMPA, nilai $P=0,917$.Terdapat perbedaan yang bermakna antara kenaikan IMT akseptor suntik kombinasi dan akseptor suntik DMPA, nilai $P=0,000$.Tidak terdapat perbedaan yang bermakna antara kenaikan tekanan darah akseptor suntik kombinasi dan akseptor suntik DMPA. Terdapat perbedaan yang bermakna antara kenaikan IMT akseptor suntik kombinasi dan akseptor suntik DMPA.

Kata Kunci: Tekanan Darah, IMT, Suntik Kombinasi dan suntik DMPA.

\section{PENDAHULUAN}

Dalam upaya penurunan Angka Kematian Ibu (AKI), program Keluarga Berencana (KB) harus dilaksanakan dengan baik, diantaranya adalah meningkatkan penggunaan kontrasepsi. Meningkatkan tingkat pemakaian KB sebagai tindakan preventif terutama bagi wanita dengan resiko 4 (empat) terlalu, yaitu terlalu muda (usia di bawah 20 tahun), terlalu tua (usia di atas 35 tahun), terlalu dekat (jarak kelahiran antara anak yang satu dengan yang berikutnya kurang dari 2 tahun), dan terlalu banyak (mempunyai anak lebih dari 2)(BKKBN, 2015).

Alat kontrasepsi sangat berguna dalam program $\mathrm{KB}$, akan tetapi tidak semua alat kontrasepsi cocok dengan kondisi setiap orang. Setiap pribadi harus bisa memilih alat kontrasepsi yang cocok untuk dirinya. Pelayanan Kontrasepsi (PK) adalah salah satu jenis pelayanan KB yang tersedia. Sebagian besar akseptor KB memilih dan membayar sendiri dari berbagai macam metode kontrsepsi yang tersedia. Banyak wanita harus menentukan pilihan kontrasepsi yang sulit. Tidak hanya karena banyaknya jumlah metode yang tersedia, tetapi juga karena metode-metode tersebut mungkin tidak dapat diterima sehubungan dengan kebijakan nasional KB, kesehatan individual, dan seksualitas wanita atau biaya untuk memperoleh kontrasepsi. Dalam memilih suatu metode, wanita harus menimbang berbagai faktor, termasuk status kesehatan mereka, efek samping potensial suatu metode, konsekuensi terhadap kehamilan yang tidak diinginkan, besarnya keluarga yang diinginkan, kerjasama pasangan, dan norma budaya mengenai kemampuan mempunyai anak (Maryani, 2008).

Pada saat sekarang ini telah banyak beredar berbagai macam alat kontrasepsi. Macam-macam metode kontrasepsi tersebut adalah intra uterine devices (IUD), implant, suntik, kondom, metode operatif untuk wanita (MOW), metode operatif untuk pria (MOP), dan kontrasepsi pil. Alat kontrasepsi hendaknya memenuhi syarat yaitu aman pemakaiannya dan dapat 3 dipercaya, efek 
samping yang merugikan tidak ada, lama kerjanya dapat diatur menurut keinginan, tidak mengganggu hubungan seksual, harganya murah dan dapat diterima oleh pasangan suami istri.Kontrasepsi hormonal merupakan jenis kontrasepsi yang paling banyak digunakan wanita terutama di negara-negara maju karena keefektifanya dalam mencegah kehamilan. Kontrasepsi hormonal adalah kontrasepsi yang mengandung hormon steroid yaitu hormon estrogen dan progesteron. Hormon yang terkandung dalam kontrasepsi hormonal adalah hormon progesteron saja atau kombinasi antara estrogen dan progesteron. Kontrasepsi hormonal yang beredar saat ini dapat berupa pil, suntik atau implan. Walaupun efektif dalam mencegah kehamilan namun tidak dapat dipungkiri timbulnya konsekuensi lain dari penggunaan alat kontrasepsi khususnya pemakaian alat kontrasepsi hormonal. Hal ini dapat menimbulkan berbagai efek samping di antaranya adalah peningkatan berat badan dan peningkatan tekanan darah pada akseptor (Baziad, 2002).

Salah satu efek samping yang disebabkan oleh kontrasepsi yang mengandung hormon progesteron yaitu terjadi perubahan pada lipid serum pada penggunaan jangka panjang, dimana didapatkan terjadi penurunan kadar High Density Lipoprotein-kolesterol (HDLkolesterol) yang dapat meningkatkan resiko meningkatnya tekanan darah (Baziad, 2002).

Kontrasepsi hormonal kombinasi juga bisa menyebabkan penyakit tekanan darah tinggi (hipertensi), pada kurang lebih $4-5 \%$ perempuan yang tekanan darahnya normal sebelum memakai kontrasepsi tersebut dan meningkatkan tekanan darah pada kurang lebih 9-16\% perempuan yang telah menderita hipertensi sebelumnya.

Hasil penelitian Kurniawati di Jakarta tahun 2010 menunjukkan bahwa pemakaian pil berisiko 3,51 kali untuk mengalami hipertensi. 11 Penelitian Septya S.K, dkk di Kota Manado tahun 2014 bahwa pengguna kontrasepsi pil berisiko 3,458 kali mengalami kejadian hipertensi pada Wanita Usia Subur (WUS) dibandingkan WUS yang tidak menggunakan kontrasepsi pil.

Penggunaan kontrasepsi pil yang mengandung hormon estrogen dan progesteron dapat menyebabkan terjadinya peningkatan tekanan darah. Hal ini disebabkan karena terjadinya hipertropi jantung dan peningkatan respon presor angiotensi II dengan melibatkan jalur Renin Angiotensin System (Olatunji dan Soladove, 2008).

Berdasarkan survey pendahuluan diperoleh data jumlah peserta KB di Wilayah Klaten tahun 2015 mencapai 154.422 akseptor. Akseptor KB tersebut terdiri dari akseptor IUD sebanyak 11.102 (7,1\%), MOW 10.332 (6,7\%), MOP 497 (3,2\%), kondom 4.163 (26,9\%), implant $21.357(13,8 \%)$, suntik $2482(61,8 \%)$, pil $11.459(7,4 \%)$. Berdasarkan data tersebut akseptor suntik paling banyak yaitu $61,8 \%$ dari keseluruhan jumlah akseptor di kecamatan Klaten Selatan. Akan tetapi kontrasepsi suntik hormonal tersebut selain efektif mencegah kehamilan tetapi juga banyak menimbulkan masalah kesehatan bagi akseptornya, diantaranya peningkatan tekanan darah sampai dengan terjadi hipertensi dan peningkatan berat badan hingga terjadi obesitas.

Dari uraian di atas, penulis tertarik melakukan penelitian tentang analisis perubahan tekanan darah dan indeks masa tubuh pada akseptor KB suntik kombinasi 
dan Depo Medroxy Progesteron Asetat (DMPA) tahun 2016.

\section{METODE PENELITIAN}

Jenis penelitian ini adalah survey analitik dengan rancangan penelitian cross sectional yaitu suatu penelitian yang mempelajari dinamika hubungan atau korelasi antara faktor-faktor risiko dengan dampak atau efeknya. Faktor risiko dan dampak atau efeknya diobservasi pada saat yang sama (Notoatmodjo, 2005). Penelitian ini dilaksanakan di wilayah kerja Puskesmas Klaten. Penelitian ini akan dilaksanakan pada bulan Juni sampai September 2016. Populasi dalam penelitian ini adalah seluruh akseptor KB suntik di wilayah kerja Puskesmas Klaten, dengan besar populasi 95.512 akseptor $\mathrm{KB}$ suntik.

Untuk menentukan besar sampel dihitung dengan rumus rumus slovinBesarsampel yang diambil peneliti adalah 500 akseptor KB suntik yang terdiri dari 250 akseptor KB suntik Kombinasi dan $250 \mathrm{~KB}$ suntik DMPA. Teknik sampling yang digunakan adalah purposive sampling. Instrumen penelitian yang digunakan dalam penelitian ini adalah lembar isian dan kuisioner. Lembar isian untuk mencatat tinggi badan, berat badan dan tekanan darah sebelum dam sesudah menggunakan suntik KB hoormonal kombinasi dan DMPA. Kuisioner digunakan utnuk memeperoleh data tentang pola aktivitas, pola makan, dan pola istirahat responden.Uji statistik yang digunakan yaitu uji MannWhitney (uji nonparametrik) dengan menggunakan bantuan program komputer SPSS 16.0 for Windows

\section{HASIL PENELITIAN}

1. Analisis Univariat

Analisis univariat digunakan untu mengetahui distribusi frekuensi karakteristik responden berdasarkan pola aktivitas, pola makan, dan pola istirahat.

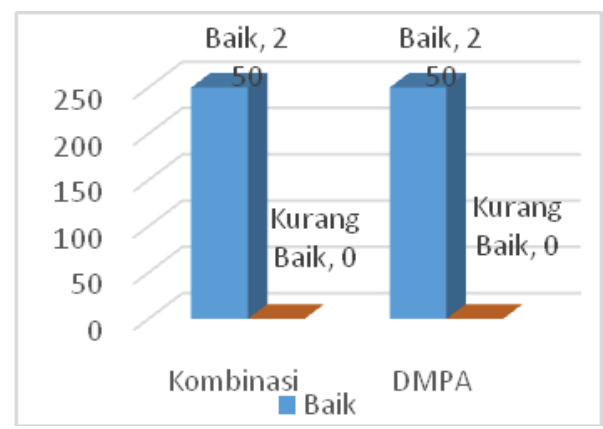

Diagram 1. Pola Aktivitas akseptor suntik Kombinasi dan DMPA

Berdasarkan diagram 1. di atas dari hasil penelitian 250 responden akseptor suntik kombinasi dan 250 akseptor suntik DMPA semuanya (100\%) mempunyai pola aktvitas yang baik.

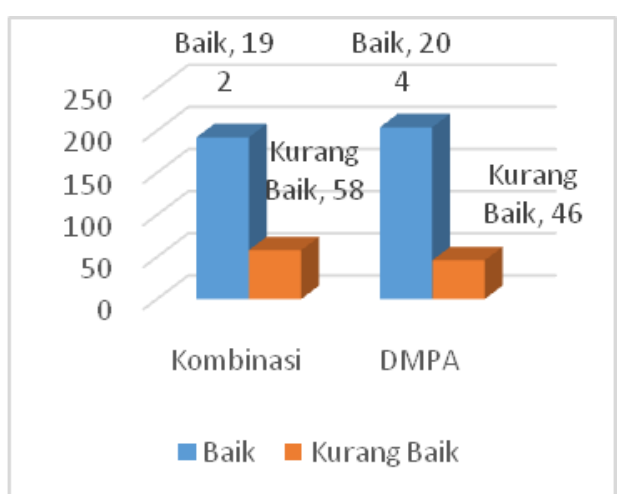

Diagram 2. Pola Makan akseptor suntik Kombinasi dan DMPA

Berdasarkan diagram 2 di atas didapatkan hasil penelitian dari 250 akseptor suntik kombinasi sebagian besar mempunyai pola makan yang baik yaitu sebanyak 192 orang $(76,8 \%)$. Pada akseptor suntik DMPA yang terdiri dari 250 akseptor sebagian besar juga 
mempunyai pola makan yang baik yaitu sebanyak $204(81,6 \%)$ akseptor.

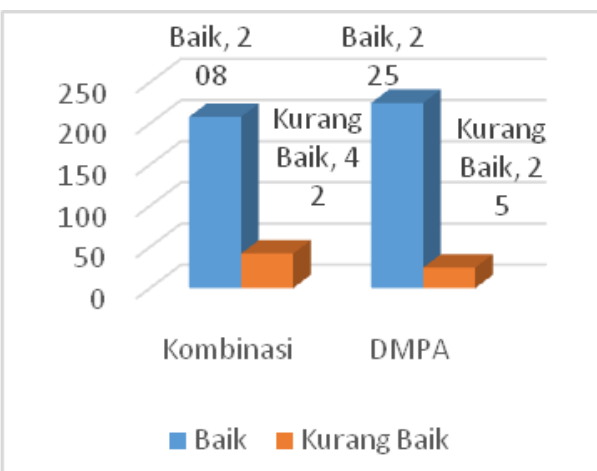

Diagram 3. Pola Istirahat akseptor suntik Kombinasi dan DMPA

Berdasarkan diagram 3. Diatas menggambarkan bahwa dari 250 akseptor suntik Kombinasi sebagian besar $(83,2 \%)$ mempunyai pola istirahat yang baik yaitu sebanyak 208 akseptor. Akseptor suntik DMPA sebagian besar (90\%) juga mempunyai pola istirahat yang baik yaitu sebanyak 225 akseptor dari 250 akseptor.

\section{Tabel 1}

Perbedaan Kenaikan Tekanan Darah Diastole Antara Akseptor Suntik Kombinasi dan Suntik DMPA

\begin{tabular}{ccccc}
\hline Akseptor & $\mathrm{N}$ & Kenaikan & \multicolumn{1}{c}{$P$ value } & \\
\cline { 3 - 4 } Suntik & & minimum & maksimum & \\
\hline Kombinasi & 250 & 0 & 30 & 0,917 \\
DMPA & 250 & 0 & 20 & \\
\hline
\end{tabular}

Analisis bivariat untuk mengetahui perbedaan kenaikan tekanan darah diastole antara akseptor suntik kombinasi dan suntik DMPA adalah menggunakan uji non parametrik yaitu uji MannWhitney. Uji Mann-Whitney digunakan karena berdasarkan uji normalitas data.

Distribusi data kenaikan tekanan darah diastole tidak normal. Hasil uji Mann-Whitney didapatkan nilai $P$ adalah0,917. Karena nilai $P>0,05$ maka dapat disimpulkan bahwa tidak ada perbedaan yang bermakna antara kenaikan tekanan darah diastole akseptor suntik kombinasi dan akseptor suntik DMPA.

\section{Tabel 2}

Perbedaan Kenaikan IMT Antara Akseptor Suntik Kombinasi dan Suntik DMPA

\begin{tabular}{ccccc}
\hline Akseptor & $\mathrm{N}$ & Kenaikan & P value & \\
\cline { 3 - 4 } Suntik & & minimum & maksimum & \\
\hline Kombinasi & 250 & 0 & 9 & 0,000 \\
DMPA & 250 & 0 & 10,5 & \\
\hline
\end{tabular}

Analisis bivariat untuk mengetahui perbedaan kenaikan IMT antara akseptor suntik kombinasi dan suntik DMPA adalah menggunakan uji non parametrik yaitu uji Mann-Whitney. Uji MannWhitney digunakan karena berdasarkan uji normalitas data, distribusi data kenaikan IMT akseptor suntik kombinasi dan DMPA adalah tidak normal. Hasil uji Mann-Whitney didapatkan nilai $P$ adalah0,000. Karena nilai $P<0,05$ maka dapat disimpulkan bahwa ada perbedaan yang bermakna antara kenaikan IMT akseptor suntik kombinasi dan akseptor suntik DMPA.

\section{PEMBAHASAN}

Menurut Kozier et al (2009), ada beberapa hal yang dapat mempengaruhi tekanan darah, diantaranya adalah umur, jenis kelamin, aktivitas fisik, ras, obatobatan dan obesitas. Responden penelitian yang merupakan akseptor kombinasi mereka mempunyai aktifitas fisik yang baik diantaranya adalah mereka melakukan kegiatan olah raga seperti senam aerobik, bersepeda, jogging dan lain-lain minimal selama 30 menit. Selain olah raga aktivitas yang dimaksud adalah melakukan kegiatan/aktivitas sehari-hari melakukan seperti mencuci, membersihkan rumah, bekerja di kantor, 
mengajar dan lain-lain selama minimal 30 menit. Aktivitas fisik adalah setiap gerakan tubuh yang membutuhkan energi untuk mengerjakannya. Aktivitas fisik yang terencana dan terstruktur yang melibatkan gerakan tubuh berulang-ulang serta yang ditujukan untuk meningkatkan kebugaran jasmani disebut olahraga. Manfaat olahraga pada lansia antara lain dapat memperpanjang usia, menyehatkan jantung, otot, dan tulang, membuat lansia lebih mandiri, mencegah obesitas, mengurangi kecemasan dan depresi, dan memperoleh kepercayaan diri yang lebih tinggi (Farizati, 2002). Orang yang kurang aktif berolahraga pada umumnya cenderung mengalami kegemukan, stres, orang yang stres dapat merangsang hormon adrenalin yang menyebabkan jantung berdenyut lebih cepat dan penyempitan kapiler sehingga tekanan darah meningkat. Aktivitas fisik akan melebarkan diameter pembuluh darah (vasodilatasi) dan membakar lemak dalam pembuluh darah jantung, sehingga aliran darah lancar.

Pola makan responden dari kelompok akseptor suntik KB Kombinasi mayoritas baik $(76,8 \%)$. Pola makan yang tidak terkontrol bisa menyebabkan penimbunan lemak sehingga mempengaruhi peredaran darah, konsumsi garam berlebih, garam bersifat menahan air sehingga menaikkan tekanan darah.

Faktor lain yang dapat meningkatkan tekanan darah adalah kualitas istirahat yaitu kualitas tidur (Susilo\&Wulandari, 2011). Dari beberapa faktor yang mempengaruhi tekanan darah, tidur merupakan fenomena dasar yang penting bagi kehidupan, kurang lebih sepertiga dari kehidupan manusia dijalankan dengan tidur. Menurut Calhoun \& Harding (2012), apabila tidur mengalami gangguan maka tidak terjadi penurunan tekanan darah saat tidur, hal tersubut akan meningkatkan resiko terjadinya hipertensi yang berujung kepada penyakit kardiovaskuler. Setiap $5 \%$ penurunan normal yang seharusnya terjadi dan tidak dialami oleh seseorang, maka kemungkinan 20\% akan terjadi peningkatan tekanan darah. Selain itu salah satu faktor dari kualitas tidur tidur yang buruk yaitu kebiasaan durasi tidur yang pendek juga dihubungkan dengan peningkatan tekanan darah. Kebutuhan waktu tidur bagi setiap orang berbedabeda, tergantung pada kebiasaan yang dibawa selama perkembangannya menjelang dewasa, akivitas pekerjaan, usia dan kondisi kesehatan (Lumbantobing, 2004).

Berdasarkan hasil penelitian dari responden pada kelompok akseptor suntik KB kombinasi mayoritas $(83,2 \%)$ kualitas istirahat atau tidur baik.

Hasil penelitian dari karakteristik responden kelompok akseptor suntik DMPA berdasar pola hidupnya yang terdiri dari pola aktivitas, pola makan dan pola istirahat adalah baik. Hasil penelitian pola aktivitas dari kelompok akseptor suntik Kombinasi semuanya baik. Mereka mempunyai aktifitas fisik yang baik diantaranya adalah mereka melakukan kegiatan olah raga seperti senam aerobik, bersepeda, jogging dan lain-lain minimal selama 30 menit. Selain olah raga aktivitas yang dimaksud adalah melakukan kegiatan/ aktivitas sehari-hari melakukan seperti mencuci, membersihkan rumah, bekerja di kantor, mengajar dan lain-lain selama minimal 30 menit. Selain itu mereka juga mayoritas mempunyai pola makan yang baik yaitu $81,6 \%$. Seperti yang telah dijelaskan di awal bahwa pola makan mempengaruhi 
tekanan darah. Kelompok akseptor suntik DMPA mayoritas (90\%) juga mempunyai pola istirahat yang baik. Pola istirahat pada penelitian ini diinterpretasikan sebagai pola tidur. Kualitas tidur juga berpengaruh pada tekanan darah.

Pola hidup pada kelompok responden akseptor suntik DMPA adalah baik, maka kenaikan tekanan darah pada akseptor suntik DMPA di sebabkan karena hormon yang terkandung pada suntikan DMPA. Depo Medroxy Progesteron Asetat (DMPA) mengandung komponen gestagen memiliki khasiar vasokonstriksi sehingga dapat menyebabkan spasme pembuluh darah dan hipertensi (Baziad, 2002). Berdasarkan hasil penelitian yang dilakukan oleh Runiari dkk tentang hubungan lama pemakaian kontrasepsi suntikan progestin dengan tekanan darah pada akseptor KB di Puskesmas II Denpasar selatan menyatakan bahwa ada hubungan yang signifikan antara lama pemakaian kontrasepsi suntikan progestin dengan tekanan darah pada akseptor KB puskesmas II Denpasar Selatan.

Hasil penelitian Indeks Massa Tubuh (IMT) dari 500 responden yang terdiri dari 250 kelompok akseptor suntik kombinasi dan 250 kelompok akseptor DMPA yang sudah menggunakan kontrasepsi suntikan tersebut selama dua tahun atau lebih didapatkan kenaikan rerata IMT. Rerata IMT dari 250 responden sebelum menggunakan $\mathrm{KB}$ suntik Kombinasi adalah 22,13 dan sesudah menggunakan KB suntik Kombinasi adalah 23,89. Terdapat kenaikan IMT pada akseptor KB suntik Kombinasi dengan nilai median 1,4. nilai minimum akseptor KB suntik Kombinasi adalah 0 dan nilai maksimum adalah 9 . Rerata IMT dari 250 responden sebelum menggunakan KB suntik DMPA adalah 21,75 dan sesudah menggunakan $\mathrm{KB}$ suntik DMPA adalah 24,13. Terdapat kenaikan IMT pada akseptor KB suntik DMPA dengan nilai median 2,1. Nilai minimum akseptor $\mathrm{KB}$ suntik DMPA adalah 0 dan nilai maksimum adalah 10,5.

Beberapa faktor yang mempengaruhi IMT diantaranya adalah pola makan dan aktivitas fisik dan faktor hormonal. Pola makanan masyarakat perkotaan yang tinggi kalori dan lemakserta rendah serat memicu peningkatan jumlah penderita obesitas. Masyarakat diperkotaan cenderung sibuk, biasanya lebih menyukai mengkonsumsi makanan cepat saji, dengan alasan lebih praktis. Meskipun mereka mengetahui bahwa nilai kalori yang terkandung dalam makanan cepat saji sangat tinggi, dan didalam tubuh kelebihan kalori akan diubah dan disimpan menjadi lemak tubuh (Soeharto,2001). Aktivitas fisik yang rutin akan membuat oksidasi lemak meningkat dan nafsu makan dapat terkontrol. Aktivitas fisik juga perlu memperhatikan intensitas, frekuensi, dan lama saat melakukan suatu aktifitas (WorthingtonRoberts, 2000)

Kenaikan rerata IMT pada akseptor suntik DMPA sesuai dengan hipotesa para ahli DMPA merangsang pusat pengandali nafsu makan di hipotalamus yang menyebabkan` akseptor makan lebih banyak daripada biasanya (Hartanto, 2002). Sebagian besar pengguna DMPA akan mengalami peningkatan berat badan sebesar 5\% dalam 6 bulan pertama (Barclay,2009). Sementara penelitian Berenson dan Rahman pada tahun 2009 menyimpulkan bahwa selama 36 bulan pengguna DMPA mengalami peningkatan berat badan 
sebanyak $5,1 \mathrm{~kg}$, lemak tubuh $4,1 \mathrm{~kg}$ dan persentase lemak tubuh $3,4 \%$.

Beberapa studi penelitian didapatkan peningkatan berat badan akibat penggunaan kontrasepsi suntik DMPA berkaitan dengan peningkatan lemak tubuh dan adanya hubungan dengan regulasi nafsu makan. Salah satu studi menemukan peningkatan nafsu makan yang dilaporkan sendiri oleh wanita yang menggunakan kontrasepsi DMPAsetelah 6 bulan (Beksinska, 2011). Hal ini dapat dihubungkan dengan kandungan DMPA yaitu hormon progesteron, yang dapat merangsang pusat pengendali nafsu makan di hipotalamus sehingga menyebabkan terjadinya peningkatan nafsu makan (Hartanto, 2002).

Hasil penelitian menunjukkan bahwa kenaikan tekanan darah sistole antara kelompok akseptor suntik kombinasi dan kelompok akseptor suntik DMPA sama-sama mengalami kenaikan. Hasil uji Mann-Whitney untuk mengetahui perbedaan kenaikan tekanan darah sistole antara kelompok akseptor suntik kombinasi dengan kelompok aksepotor DMPA didapatkan nilai $\mathrm{P}$ adalah0,338. Karena nilai $\mathrm{P}>0,05$ maka dapat disimpulkan bahwa tidak ada perbedaan yang bermakna antara kenaikan tekanan darah sistole akseptor suntik kombinasi dan akseptor suntik DMPA. Keduanya mempunyai risiko untuk meningkatkan kenaikan darah sistole pada akseptor. Kenaikan maksimum pada akseptor suntik kombinasi setelah pemakaian dua tahun atau lebih bisa mencapai $30 \mathrm{mmhg}$. Sementara kenaikan maksimum pada akseptor suntik DMPA setelah penggunaan dua tahun atau lebih dapat mencapai $40 \mathrm{mmhg}$.
Kontrasepsi suntik kombinasi yang mengandung hormon estrogen dan progesteron akan menyebabkan terjadinya peningkatan tekanan darah yang dihubungkan dengan hipertropi jantung dan peningkatan respon presor angiotensin II dengan melibatkan jalur Renin Angiotensin System (Olatunji dan Soladoye,2008).

Depo Medroxy Progesteron Asetat (DMPA) mengandung komponen gestagen memiliki khasiat vasokonstriksi sehingga dapat menyebabkan spasme pembuluh darah dan hipertensi (Baziad, 2002).

Kontrasepsi suntik DMPA yang mengandung progesteron menyebabkan terjadinya perubahan pada lipid serum pada penggunaan jangka panjang, dimana didapatkan terjadi penurunan kadar High Density Lipoprotein-kolesterol (HDLkolesterol) yang dapat meningkatkan resiko meningkatnya tekanan darah. Penelitian ini didukung oleh penelitian yang dilakukan oleh Sanger, dkk (2008) mengenai pengaruh suntikan depo medroxy progesteron asetat terhadap profil lipid, dimana didapatkan terjadi penurunan kadar HDL-kolesterol. Setelah 12 bulan pemakaian. Terjadinya penurunan kadar HDL-kolesterol akan meningkatkan resiko meningkatnya tekanan darah. Hal ini sesuai dengan pernyataan Saifuddin (2006), yang mengatakan bahwa salah satu kerugian dari pemakaian KB suntikan depoprovera (salah satu jenis dari suntikan DMPA) yaitu terjadi perubahan pada lipid serum pada penggunaan jangka panjang. Selain itu, penelitian yang dilakukan oleh Umi Faristin di Semarang tahun 2005, menyatakan bahwa dari 100 responden yang menggunakan kontrasepsi suntikan depoprovera, terdapat 22 orang responden 
yang mengalami peningkatan tekanan darah dan 88 orang yang tekanan darahnya tetap.

Efek depoprovera pada sistem kardiovaskuler yaitu adanya sedikit peninggian dari kadar insulin dan penurunan HDL-kolesterol. Kolesterol tidak larut dalam air ataupun darah. Kolesterol diangkut ke berbagai jaringan dalam tubuh dengan bantuan senyawa yang tersusun atas lemak dan protein yaitu lipoprotein. Kolesterol LDL (low density lipoprotein) cenderung tersimpan dalam arteri. Kondisi ini berakibat buruk karena jika kadar kolesterol LDL > $130 \mathrm{mg} / \mathrm{dl}$ sedangkan HDL mengalami penurunan yaitu < $40 \mathrm{mg} / \mathrm{dl}$ maka ini merupakan risiko akan terjadi peningkatan tekanan darah (Hartanto, 2002). Menurut Varney (2001) efek samping dari kandungan hormon progesteron yang berlebihan pada sistem kardiovaskuler dapat menyebabkan perubahan tekanan darah.

Resiko terjadinya tekanan darah tinggi akan meningkat dengan bertambahnya umur, lama pemakaian kontrasepsi dan bertambahnya berat badan. Perubahan berat badan ini disebabkan karena hormon progesteron mempermudah perubahan karbohidrat dan gula menjadi lemak, sehingga lemak banyak yang bertumpuk di bawah kulit dan bukan merupakan karena retensi (penimbunan) cairan tubuh, selain itu depoprovera juga merangsang pusat pengendali nafsu makan di hipotalamus yang dapat menyebabkan akseptor makan lebih banyak dari biasanya, sehingga orang yang kelebihan lemak (hiperlipidemia), berpotensi mengalami penyumbatan darah sehingga suplai oksigen dan zat makanan ke organ tubuh terganggu (Hartanto, 2002). Penyempitan dan sumbatan oleh lemak ini memacu jantung untuk memompa darah lebih kuat lagi agar dapat memasok kebutuhan darah ke jaringan. Akibatnya, tekanan darah meningkat, maka terjadilah tekanan darah tinggi. Sehingga diketahui pemakaian kontrasepsi depoprovera merupakan salah satu faktor pendukung munculnya tekanan darah tinggi apabila kontrasepsi ini digunakan dalam jangka waktu panjang.

Hasil penelitian menunjukkan bahwa kenaikan tekanan darah diastole antara kelompok akseptor suntik kombinasi dan kelompok akseptor suntik DMPA sama-sama mengalami kenaikan. Hasil uji Mann-Whitney untuk mengetahui perbedaan kenaikan tekanan darah diastole antara kelompok akseptor suntik kombinasi dengan kelompok aksepotor DMPA didapatkan nilai $P$ adalah 0,917 . Karena nilai $P>0,05$ maka dapat disimpulkan bahwa tidak ada perbedaan yang bermakna antara kenaikan tekanan darah diastole akseptor suntik kombinasi dan akseptor suntik DMPA.

$$
\text { Berdasarkan hasil penelitian }
$$
didapatkan bahwa kedua kontrasepsi sama-sama dapat meningkatkan kenaikan tekanan diastole. Berdasarkan penelitian pada 250 akseptor suntik kombinasi setelah menggunakan suntikan KB kombinasi selama dua tahun atau lebih dapat meningkatkan tekanan darah diastole maksimum $30 \mathrm{mmhg}$. Sementara pada kelompok akseptor suntik DMPA setelah menggunakan suntikan KB DMPA selama dua tahun atau lebih terdapat kenaikan maksimum 20 mmhg.

Suntikan kombinasi mengandung hormon estrogen dan progesteron, dapat meningkatkan tekanan darah akibat pengaruh estrogennya. Estrogen dapat meningkatkan kadar aldosteron, hal ini disebabkan karena peningkatan substrat renin plasma (angiotensinogen) dan 
aktivitas renin dalam plasma. Kadar angiotensin II meningkat sehingga akan menstimulasi produksi aldosteron. Kadar aldosteron dalam plasma yang tinggi akan mempercepat kejadian hipertensi terakselerasi yang khas ditandai dengan kenaikan diastole. (Greenspan dan Baxter, 2000).

Depo Medroxy Progesteron Asetat (DMPA) mengandung komponen gestagen memiliki khasiat vasokonstriksi sehingga dapat menyebabkan spasme pembuluh darah dan hipertensi (Baziad, 2002). Kontrasepsi suntik DMPA yang mengandung progesteron menyebabkan terjadinya perubahan pada lipid serum pada penggunaan jangka panjang, dimana didapatkan terjadi penurunan kadar High Density Lipoprotein-kolesterol (HDLkolesterol) yang dapat meningkatkan resiko meningkatnya tekanan darah. Penelitian ini didukung oleh penelitian yang dilakukan oleh Sanger, dkk (2008) mengenai pengaruh suntikan depo medroxy progesteron asetat terhadap profil lipid, dimana didapatkan terjadi penurunan kadar HDL-kolesterol. Setelah 12 bulan pemakaian. Terjadinya penurunan kadar HDL-kolesterol akan meningkatkan resiko meningkatnya tekanan darah. Hal ini sesuai dengan pernyataan Saifuddin (2006), yang mengatakan bahwa salah satu kerugian dari pemakaian KB suntikan DMPA yaitu terjadi perubahan pada lipid serum pada penggunaan jangka panjang.

Hasil penelitian menunjukkan bahwa kenaikan IMT antara kelompok akseptor suntik kombinasi dan kelompok akseptor suntik DMPA sama-sama mengalami kenaikan. Rerata kenaikan IMT kelompok akseptor suntik DMPA lebih besar dibandingkan dengan rerata kenaikan IMT pada kelompok akseptor kombinasi. Rerata kenaikan IMT kelompok akseptor kombinasi adalah 1,973 sementara rerata kenaikan kelompok akseptor DMPA adalah 2,51. Hasil uji Mann-Whitney untukmengetahui perbedaan kenaikan IMT antara kelompok akseptor suntik kombinasi dengan kelompok akseptor DMPA didapatkan nilai $P$ adalah 0,00 . Karena nilai $P<0,05$ maka dapat disimpulkan bahwa ada perbedaan yang bermakna antara kenaikan IMT akseptor suntik kombinasi dan akseptor suntik DMPA.

Kenaikan IMT pada akseptor kombinasi bisa dijelaskan bahwa kontrasepsi suntik kombinasi yang mengandung hormon estrogen dan progesteron dapat meningkatkan berat badan bagi penggunanya. Hal tersebut dapat dijelaskan bahwa estrogen mempunyai efek kurangnya pengeluaran air dan natrium sehingga terjadi retensi cairan yang dapat menyebabkan meningkatnya berat badan. Sementara progesteron memunyai efek androgenik yang dapat menyebabkan bertambahnya nafsu makan dan efek metabolik hormon sehingga berat badan menjadi meningkat (hartanto, 2002).

DMPA merupakan metode kontrasepsi hormonal suntik yang hanya mengandung progesteron, memiliki angka kegagalan $<1 \%$ pertahun,yang diberikan secara injeksi intramuskular setiap 3 bulan dengan dosis150mg. Namun dalam penggunaannya, DMPA ini memiliki beberapa efek samping seperti gangguan pola menstruasi dan penambahan beratbadan (Hartanto,2002). Sebagian besar pengguna DMPA akan mengalami peningkatan berat badan sebesar $5 \%$ dalam 6 bulan pertama (Barclay,2009). Penelitian Berenson dan Rahman pada 
tahun 2009 menyimpulkan bahwa selama 36 bulan,pengguna DMPA mengalami peningkatan beratbadan sebanyak $5.1 \mathrm{~kg}$,lemak tubuh $4.1 \mathrm{~kg}$, dan persentase lemak tubuh 3.4\%. Beksinskaetal (2001) dalam artikelnya menyatakan bahwa dari studi-studi penelitian didapatkan peningkatan berat badan akibat penggunaan kontrasepsi DMPA berkaitkan dengan peningkatan lemak tubuh dan adanya hubungan dengan regulasi nafsu makan. Salah satu studi menemukan peningkatan nafsu makan yang dilaporkan sendiri oleh wanita yang menggunakan kontrasepsi DMPA setelah 6 bulan. Hal ini dapat dihubungkan dengan kandungan pada DMPA yaitu hormon progesteron, yang dapat merangsang pusat pengendalian nafsu makan dihipotalamus (Guyton,2007) sehingga menyebabkan terjadinya peningkatan nafsu makan.

Kenaikan rerata IMT pada akseptor suntik DMPA sesuai dengan hipotesa para ahli DMPA merangsang pusat pengandali nafsu makan di hipotalamus yang menyebabkan` akseptor makan lebih banyak daripada biasanya (Hartanto, 2002). Sementara penelitian Berenson dan Rahman pada tahun 2009 menyimpulkan bahwa selama 36 bulan pengguna DMPA mengalami peningkatan berat badan sebanyak $5,1 \mathrm{~kg}$, lemak tubuh $4,1 \mathrm{~kg}$ dan persentase lemak tubuh $3,4 \%$. Penambahan berat badan merupakan salah satu alasan akseptor menghentikan kontrasepsi suntik DMPA(Polaneczky,etal dalam Berenson dan Rahman,2009).

Beberapa studi penelitian didapatkan peningkatan berat badan akibat penggunaan kontrasepsi suntik DMPA berkaitan dengan peningkatan lemak tubuh dan adanya hubungan dengan regulasi nafsu makan. Salah satu studi menemukan peningkatan nafsu makan yang dilaporkan sendiri oleh wanita yang menggunakan kontrasepsi DMPAsetelah 6 bulan (Beksinska, 2011). Hal ini dapat dihubungkan dengan kandungan DMPA yaitu hormon progesteron, yang dapat merangsang pusat pengendali nafsu makan di hipotalamus sehingga menyebabkan terjadinya peningkatan nafsu makan (Hartanto, 2002).

\section{KESIMPULAN DAN SARAN}

Berdasarkan dari hasil penelitian dapat disimpulkan bahwa tidak terdapat perbedaan yang bermakna antara kenaikan tekanan darah akseptor suntik kombinasi dan suntik DMPA. Terdapat perbedaan yang bermakna antara kenaikan IMT akseptor suntik Kombinasi dan Suntik DMPA.

Berdasarkan dari kesimpulan di atas maka saran yang diberikan kepada petugas kesehatan adalah agarselalu memberikan penjelasan yang lengkap terhadap efek samping dari penggunaan kontrasepsi khususnya kontrasepsi hormonal. Selain itu selalu melakukan skrining pada semua calon akseptor $\mathrm{KB}$ suntik hormonal baik suntik kombinasi maupun suntik DMPA. Salah satunya adalah melakukan pemeriksaan tekanan darah. Pada calon akseptor yang menderita hipertensi atau prehipertensi diharapkan petugas kesehatan (bidan) tidak menyarankan menggunakan KB suntik hormonal baik kombinasi maupun DMPA.Petugas kesehatan yang memberikan pelayanan kontrasepsi (bidan, dokter dll) diharapkan selalu memantau Indeks massa Tubuh (IMT) akseptor KB suntik baik kombinasi maupun DMP atau setidaknya berat badan akseptor secara rutin dan teliti setiap kali kunjungan ulang sehingga berat badan 
atau IMT akeptor terkontrol untuk mencegah terjadinya overweigth. Bagi calon akseptor KB suntik yang tidak menginginkan peningkatan berat badan yang banyak atau calon akseptor yang sudah mempunyai indeks massa tubuh yang lebih dari normal disarankan untuk menggunakan KB suntik Kombinasi.

\section{DAFTAR RUJUKAN}

Barclay L.2009. Predictors of excessive weight gain with injectable birth control identified. Obstet Gynecol. 2009; 114:279-84.

Baziad A. 2002. Kontrasepsi Hormonal. Jakarta: Yayasan Bina Pustaka Sarwono Prawirohardjo.

Beksinska ME, Smit JA, Guidozzi F.2011. Weigth Change and Hormonal Contraception. Expert Rev Obstet Gynecol. 6 (1): 45-56.

BKKBN.2013. Rakornas Kemitraan BKKBN dengan IBI dan IDI. (Diunduh 22 Januari 2016). Tersedia dari: http://www..bkkbn.go.id.

Francis S, Baxter GJD. 2000. Endokrinologi Dasar \& Klinik. Jakarta: EGC.

Guyton AC, Hall JE.2007. Buku ajar fisiologi kedokteran (terjemahan). Edisi ke-11. Jakarta: Penerbit Buku Kedokteran EGC

Hartanto H.2004. Keluarga berencana dan kontrasepsi. Jakarta: Pustaka Sinar Harapan.

Kurniawati, H. 2010. Hubungan Pemakaian Kontrasepsi pil KB Kombinasi dengan Tekanan Darah
Tinggi pada Wanita Usia Subur di Puskesmas Kecamatan Grogol Petamburan Jakarta Barat Tahun 2010. Tesis, Program Pascasarjana, Depok: Fakultas Kesehatan Masyarakat Universitas Indonesia.

Maryani, S., Suratun, Hartini,T., Rusmiati, \& Pinem S (2008). Pelayanan Keluarga Berencana \&Pelayanan Kontrasepsi. Jakarta: TIM.

Notoatmodjo, S. 2003. Metodologi Penelitian Kesehatan. Jakarta: Rineka Cipta.

Olatunji LA., Soladove AO. 2008. Oral Contraceptive InduceBlood Pressure is Prevented by Renin Angiotensin Suppression in Female Rats But Not By Sympathetic Nervous System Blokade. Indian Journal of Experimental Biology , 46 (11): 749-754.

Saifuddin, A.B.2006. Buku Panduan Praktis Pelayanan Kontrasepsi. Jakarta: Yayasan Bina Pustaka Sarwono Prawirohardjo.

Septya S.K. dkk.2014. Hubungan antara Penggunaan Kontrasepsi Pil dengan Kejadian Hipertensi Pada Wanita Usia Subur di Wilayah Kerja Puskesmas Bahu Kota Manado. Tersedia dari: $<$ fkm.unsrat.ac.id/wp-conten/ uploads/2014/10/Septya-k.pdf> [Accessed 27 December 2015].

Sugiyono.2010. Metode Penelitian Kuantitatif dan Kualitatif. Bandung: Alfabeta. 